\title{
Removal of Copper from Industrial Wastewater and its Relationship with Wilson's Disease
}

\author{
Type of article: Original \\ Keniche Assia ${ }^{1,2}$, Leshaf Anissa ${ }^{1}$, Kidari Oussama ${ }^{1}$, Kadire Mazari $^{1}$, Khelassi Asma ${ }^{1}$, Fatoumata \\ Samake ${ }^{2}$ \\ ${ }^{1}$.Maghnia Center University, Departement of Hydraulic, 13000,Maghnia, Algeria. \\ ${ }^{2}$ Laboratory of Organic Chemistry Natural Products and Analysis, University of Tlemcen.
}

\begin{abstract}
Background: Wilson's illness, or hepato-lenticular degeneration, is an autosomal passive issue that outcomes from an accumulation of copper prevalently in the liver and brain. The aggregation is happen because of imperfect biliary discharge of copper. Current information demonstrates that grown-up people need to ingest about $0.75 \mathrm{mg}$ of copper every day to continue a parity. Because of a hereditary imperfection, people with Wilson's ailment cannot discharge the abundance copper, bringing about a progressive develop of copper in the body. Substantial metals are the most hurtful of the concoction toxins and are of specific worry because of their poison levels to people. From this poisonous metal copper, which has impacts in drinking water on the gastrointestinal tract, yet there is some with respect to the drawn out impacts of copper on delicate populaces, for example, bearers of the quality for Wilson's malady and other metabolic issue of copper homeostasis.

Method: We picked as a characteristic adsorbent in this work the Moringa Oleifera Seeds (MOSs) from Mali assortment, which could be a practical and earth safe strategy for water sanitization. All examinations were directed at room temperature, and after being permitted to represent two hours, the examples were broke down utilizing the Atomic Absorption Spectrophotometer (AAS). The seeds of Moringa were set up by taking around $1 \mathrm{~g}$ of the seed squashed and blending it in with around $20 \mathrm{~cm}^{3}$ of water to be decontaminated in three distinct measuring utensils.

Result: The different arrangements after filtration, indicated an expanded thickness in the amount of copper, which demonstrates the viability of the cleansing intensity of the seeds of MO. The best consequences of absorption were for 30 min of contact time. We had half copper evacuation. The impact of contact time is significant in biosorption investigations to decide the harmony time required for the take-up of metal particles by the MOSs.

Conclusion: In this investigation, the MOS from Mali were demonstrated to be a proficient regular adsorbent material of copper from fluid arrangements. The limit of the MOS to evacuate copper relies upon numerous models as; plant assortment and states of examinations. Our examination is going on the investigation of evacuation parameters, for example, contact time, $\mathrm{pH}$, temperature, molecule size, sorbent portion, and introductory metal fixation.
\end{abstract}

Keywords: Copper, MoringaOleifera Seeds, Wilson's Disease,Water purification, Bioremediation, Sustainable development.

Corresponding author: Keniche Assia,Maghnia Center University, Departement of Hydraulic, 13000,Maghnia, Algeria.COSNA laboratory, university of Tlemcen, Algeria. e-mail: keniche_assia@ yahoo.fr, Tel/Fax :0021343265886 Received: 28 February 2020, Accepted: 09 April, 2020, Published: 05 June, 2020.

Screened by iThenticate.O2017-2020 KNOWLEDGE KINGDOM PUBLISHING.

\section{Introduction}

Given the current state of public health and the need to reduce the Carbon Footprint (CF) several research works have been trying to reuse all types of garbage and residues $[1,2,3,4]$. This work focuses about the expulsion of substantial metals from wastewater. Particularly, copper, whose impacts on living creatures can be devastating. In human beings, copper can cause Wilson's Disease.

Water is an asset that is basic forever and is required by pretty much every living being. Water contamination is a major issue particularly in creating nations on the planet. The water secured about $71 \%$ of the all-out earth's surface and groundwater. Water is one of the more demandable of all urban and rustic enhancements and essential for human exercises counting water for drinking and water system, 
recreational chances and natural surroundings for monetarily significant fisheries. Contamination represents a genuine hazard to life, particularly when the water is a wellspring of drinking and for household purposes for people; contaminated waters are strong specialists of maladies [5].

This asset is, in any case, getting restricted in its unadulterated state because of thousands of synthetic concoctions that have been distinguished in drinking water supplies far and wide and are considered possibly perilous to human wellbeing at generally high concentrations World Health Organization (WHO) in 2004 [6]. Overwhelming metals are the most destructive of the concoction toxins and are of specific worry because of their poison levels to people [7]. Metals and metalloids with nuclear loads extending from 63 to $200.6 \mathrm{~g} / \mathrm{mole}$ and densities more noteworthy than $4.5 \mathrm{~g} / \mathrm{cm}^{3}$ are steady in nature [8] .This poisonous metal has impacts in drinking water on the gastrointestinal tract. In any case, there is some vulnerability with respect to the drawn out impacts of copper on delicate populaces, for example, bearers of the quality for Wilson's disease and other metabolic issue of copper homeostasis [9].

\subsection{Wilson's Disease}

Wilson's Disease (WD) is a genetic disorder that causes excessive amounts of copper to accumulate in the body, affecting the liver and brain. Instead of the body eliminating the excess copper, it absorbs from food, for people with Wilson's disease, the copper accumulates, causing tissue damage.

Common signs of liver disease are

i. A yellow skin discoloration (jaundice),

ii. Mucous membranes,

iii. Swelling (edema) of the legs and abdomen (ascites) because of abnormal fluid retention,

iv. Frequency of anomalous veins in the throat, which may drain,

v. Bruising propensity,

vi. Persistent bleeding,

vii. Extreme fatigue.

A few people with Wilson's sickness may have just variations from the norm of liver capacity tests and may show no different side effects until numerous years after the fact. A minority may encounter genuine liver disappointment. This stake place frequently in young people with Wilson's illness and more women are increasingly influenced. These individuals may rapidly give indications and side effects of liver illness, as often as possible identified with sickliness due to the red platelet breakdown (hemolysis) and mental disarray. These youthful patients may not show the unmistakable corroded earthy colored stores in the corneas (KayserFleischer rings).

The patient may develop neurologic (brain-related) symptoms when the liver symptomatology is hidden. Common neurological symptoms may appear, and progress with time are tremor, trouble gulping (dysphagia), automatic developments, talking challenges, poor explanation (dysarthria), spasticity, discoordination, dystonic stances, and strong unbending nature. Practically totally influenced people with neurological indications have Kayser-Fleischer rings in their eyes effortlessly perceived by an ophthalmologist.

This sickness can cause mental indications that vary extensively in patients; with manifestations going from gloom to schizophrenia. It is now and again erroneously analyzed as substance misuse. Vacillations in character or conduct may occur. Most people harrowed by this disease have neurologic side effects correspondingly 
or will introduce them in around three years (with Kayser-Fleischer rings on their corneas).

Young females may have faulty or even the cessation of menstruation until the disease is treated because of hormonal disturbances due to an ill-functioning liver, as it is the case with WD. Unnatural birth cycles and barrenness are likewise repetitive.

Extra signs and cautioning indications of Wilson's sickness may contain kidney stones, renal rounded harm, early joint pain, and other bone and joint associations, e.g., osteoporosis, the advent of bony outgrowths (aka osteophytes) on large joints, along with a reduction of spinal and extremity joint spaces.

The examination in [10] reports the case history of a kid who introduced at 14 months with ascites and was found to have extreme micronodular cirrhosis with biochemical proof of Wilson's ailment. In any case, given the seriousness of the pathology and early period of introduction, the chance of incessant copper harming was explored. It was discovered that the kid's drinking water originated from a drag through new copper pipes. The drag water had a $\mathrm{pH}$ of 4.4, and after entry through copper pipes had an extremely high copper level of $675 \mu \mathrm{g} / 100 \mathrm{ml}$. He in this manner passed on from liver disappointment, and at necropsy, high copper levels were found in his liver [10].

\subsection{Wilson's Disease Treatment}

The WD treatment is deep rooted. It consists to bring down the copper level to nontoxic level, and to keep the malady movement, while attempting to return any existent signs and side effects brought about copper amassing. Treatment is triple: (I) treatment of suggestive patients, (ii) upkeep treatment after the copper has been decreased in influenced tissues, and (iii) support treatment in asymptomatic patients.

Three kinds of prescriptions are utilized. At first, the substances that dispose (chelate) copper from the body by means of urinary discharge like penicillamine (or Cuprimine) and trientinedihydrochloride (or Syprine). Next, zinc salts to restrain the gut from retaining copper from the food. At long last, the tetrathiomolybdate forestalls the ingestion of copper and ties up the harmful blood copper to make it nontoxic.

A mix of trientine and zinc for 4-6 months can get patients with mellow moderate liver disappointment successfully. At that point, they may embark on maintenance treatment with zinc or trientine alone. Penicillamine and zinc are a subsequent option, yet penicillamine presents more reactions than zinc. Patients with serious liver disappointment may require liver transplantation. The ones with neurological problems can do better with tetrathiomolybdate, which is not readily available. The second choice may also involve zinc alone depending on the case, but zinc acts rather slow. Still, it does not worsen the drug catalyzation as it is so familiar with penicillamineand trientine. Trientine and penicillamine are sub-par choices to treat neurologically affected patients. This is a result of the continuous occurrence of neurological intensifying, from which a few patients never recover.

Zinc Acetate (Galzin) is standard for the upkeep of the treatment for patients. For influenced people without side effects (asymptomatic) or for people at first treated with chelating specialists, zinc acetic acid derivation is utilized to forestall copper retention from the gut. Zinc treatment is regularly favored in youngsters and pregnant ladies as a result of restricted symptoms. For some patients, narrow minded of zinc because of gastric aggravation, upkeep treatment with trientine might be ideal. 
Ceaseless medication treatment observing incorporates clinical subsequent meetups, estimations of copper levels (and zinc levels for those on zinc treatment) in 24-hour pee assortment, hematological tests to decide the amount of copper not bound to ceruloplasmin (otherwise known as free copper), occasional appraisal of liver capacities, and blood component checks. Standard urinalysis ought to likewise be done in patients utilizing chelating specialists to look for cells or protein in the pee. Rehashed liver biopsies are generally not expected to follow the medication treatment progress.

Discontinuation of medication may cause a fast accumulation of copper and threaten life. Patients utilizing zinc acetate must employ its prescription version since nutritious supplements may not be bioequivalent and may be useless. For some patients, liver transplantation may be the only way out.

The next Sections will discuss the proposed technology.

\section{Materials and methods}

Admission of low dose of copper in the eating routine can bring about lack, and high fixations can bring about harmfulness. In normal case, there is a scope of satisfactory admission, which will meet copper necessities without danger of poisonousness. Largely, copper consumption through eating routine seems to fall inside this range for the normal person. Regularly, just a little portion of a person's admission of copper gets from drinking water; along these lines, drinking water ought not to be depended upon as a significant source to meet day-by-day copper prerequisites. Then again, drinking destructive waters held in copper plumbing can bring about copper overabundance, and the potential for copper poisonousness is a public health problem.

With the expansion of mechanical exercises, copper expulsion forms have become increasingly significant. The expulsion of copper from watery arrangements has been done by strategies, for example, compound precipitation [11], particle trade [12], particle buoyancy [13], electrolytic techniques [14], turn around assimilation [15], dissolvable extraction [16], and adsorption. 
Medical Technologies Journal, Volume: 4, Issue: 1, January-March 2020, Pages: 504-515.

Doi :https://doi.org/10.26415/2572-004X-vol4iss1p504-515

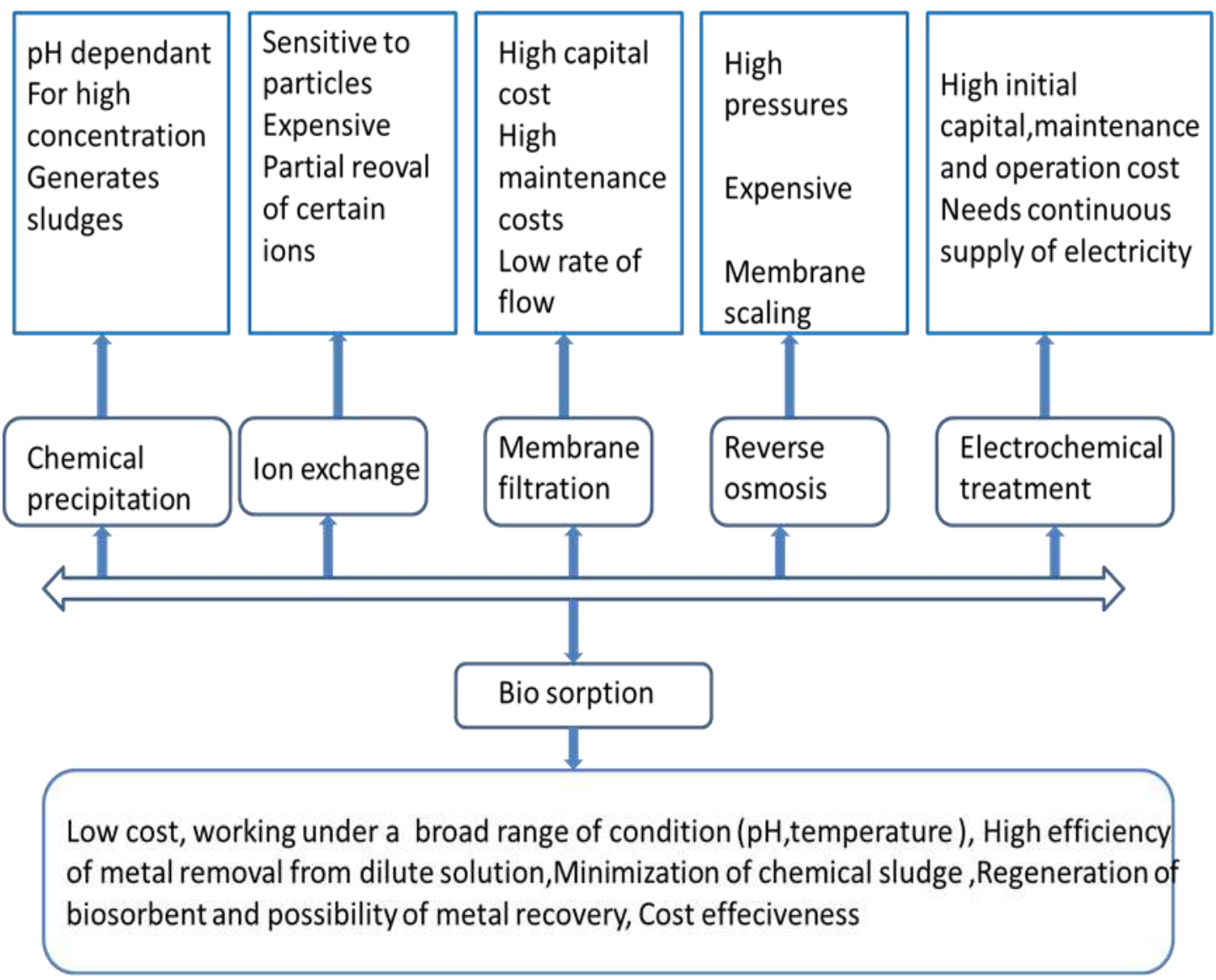

Figure 1: Drawbacks of different processes to remove heavy metals and advantages of biosorption.

Adsorption strategies do offer the most useful strategy for treating water. There still exists a need to build up a minimal effort and effective adsorbent for the expulsion of overwhelming metals from wastewater [17]. Biomaterials (i) show great adsorption limit with respect to an assortment of contaminations (even at low fixations), (ii) don't require any preparing, being earth inviting/economical, and (iii) locally accessible at extremely ease. They additionally exhibit specific adsorption for specific contaminants, for example, metal particles lastly can possibly be helpfully recovered [18]. Different wellsprings of non-business adsorbents are schematically spoken to in Fig. 1. A large number of them have been tried and proposed for evacuation of $\mathrm{As}$ (V), $\mathrm{Pb}$ (II), $\mathrm{Cd}(\mathrm{II})$ and $\mathrm{Hg}$ (II) particles from watery arrangements [19]. 


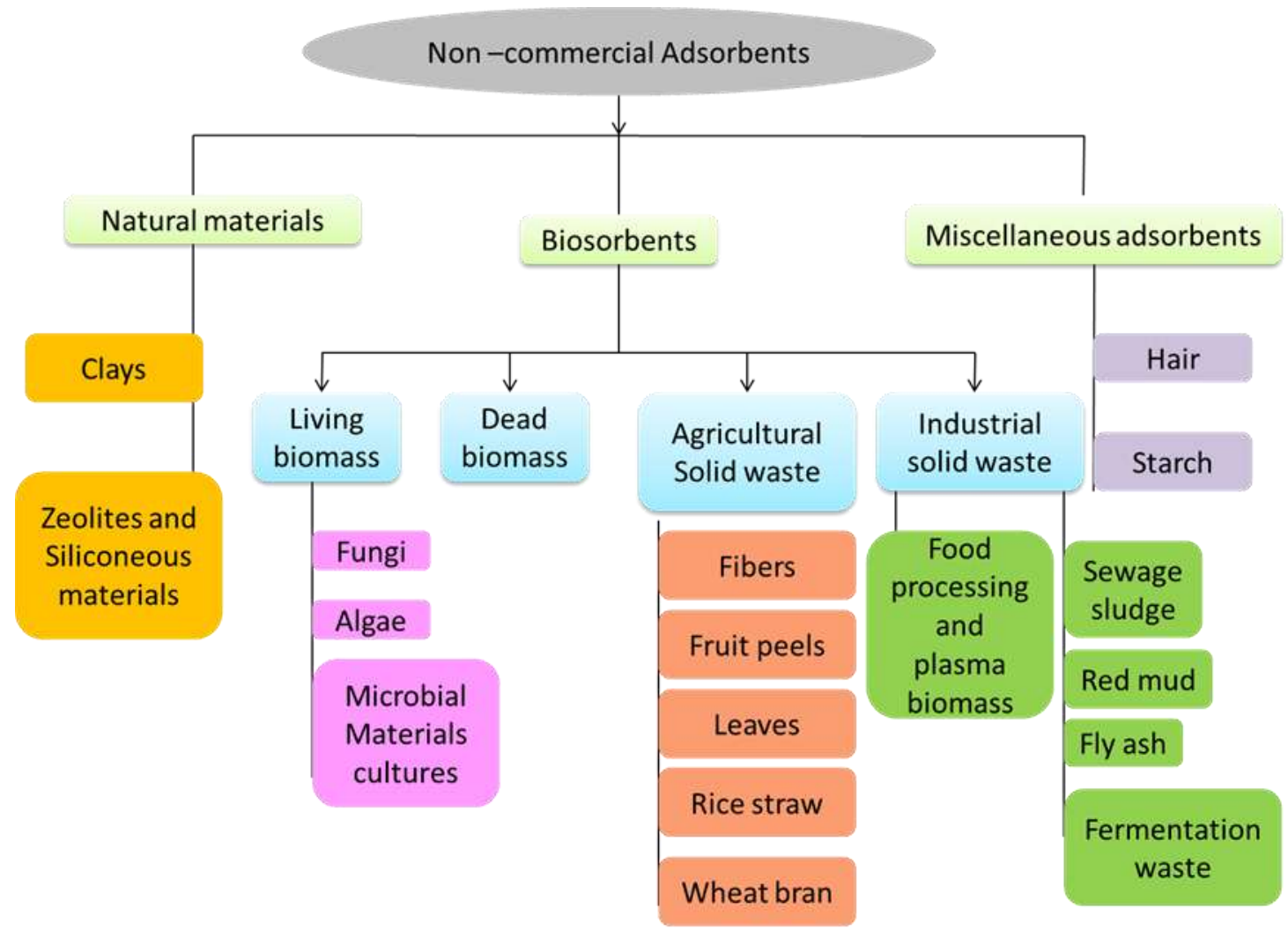

Figure 2 : Schematic representation of different sources of non-commercial adsorbents.

We choose as a characteristic adsorbent in this work Moringa Oleifera Seed (MOS) from Mali assortment, which can be a conservative and ecologically safe technique for water cleaning. Moringa Oleifera (MO) grows generally in numerous tropical areas of the reality where general wellbeing is compromised by hazardous drinking water [20], and its seeds can be utilized to treat drinking water[21,22]

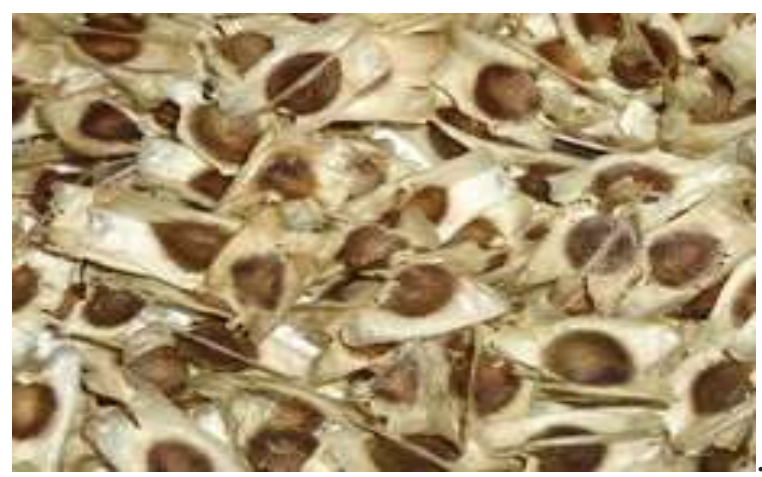

Figure 3 : Vegetable materials used: seeds of Moringa Oleifera (Mali variety).

All trials were led at room temperature, and in the wake of being permitted to represent two hours, the examples were investigated utilizing the Atomic Absorption Spectrophotometer (AAS). The seed of Moringa were set up by taking around $1 \mathrm{~g}$ of the seed squashed, and blending it in with around $20 \mathrm{~cm}^{3}$ of water to be cleansed in three unique measuring utensils. The chronometer is turned at the 
time of addition. The beakers are stirred at room temperature for 30 minutes for the first beaker and $1 \mathrm{~h} 10 \mathrm{~min}$ for the second and $2 \mathrm{~h}$ for the third.

In the end, the solution is filtered, and then analyzed by using the AAS.

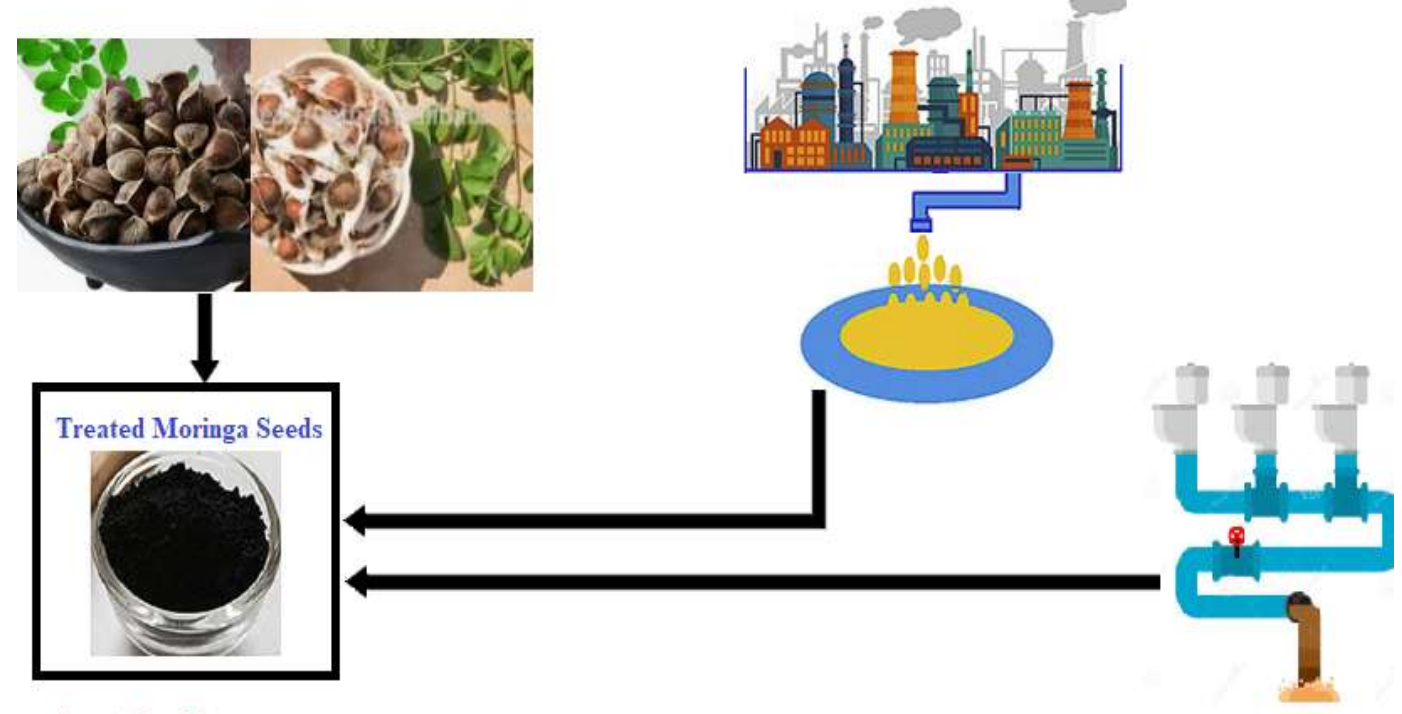

Sustainable

Water Treatment and Processing

\section{Potable Water}

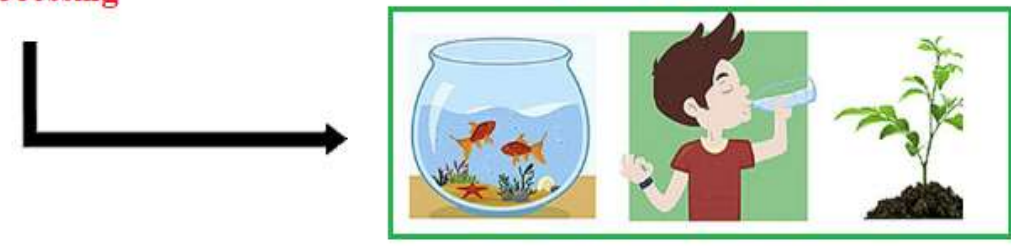

Figure 4 : Sustainable water treatment with Moringa Oleifera seeds.

\subsection{MO Seeds Pre-Treatment: Oil Extraction by Hexane}

Oil was removed by using the Soxhlet in which is found $11.13 \mathrm{~g}$ seed powder placed in a soxlet with $210 \mathrm{ml}$ of hexane. The mixture is treated for 6 hours. The solvent is then evaporated under vacuum. The seeds, after extraction of their oils, are washed and dried for the removal of copper.

\section{Result and discussion}

Our initial phase in this work was extricated oil utilizing hexane to acquire seed cake without oil, because MO seed contains 35-40\% oil. The presence of oil in MO seed affects the coagulant and overwhelming metal expulsion exercises; hence, MO seed's high oil substance would disable the wastewater treatment process [23].

The different arrangements after filtration demonstrated an expanded thickness in the amount of copper, which demonstrates the adequacy of the purging intensity of the seeds of MO. As the accompanying diagram appears, the best after effects of adsorption were for $30 \mathrm{~min}$ of contact time. We had half copper expulsion. The impact of contact time is significant in biosorption investigations to decide the balance time required for the take-up of metal particles by MOS. Watery metal particle arrangements were stayed in touch while with sorbent for $0.5,1$, and $2 \mathrm{~h}$. 
The blends were string with $200 \mathrm{rpm}$ and sifted preceding investigation of the supernatant with AAS. The adsorption of metals utilizing Moringa is constrained to the adsorption surface. This is on the grounds that Moringa is a cationic polyelectrolyte of short-chain and low atomic weight [24].

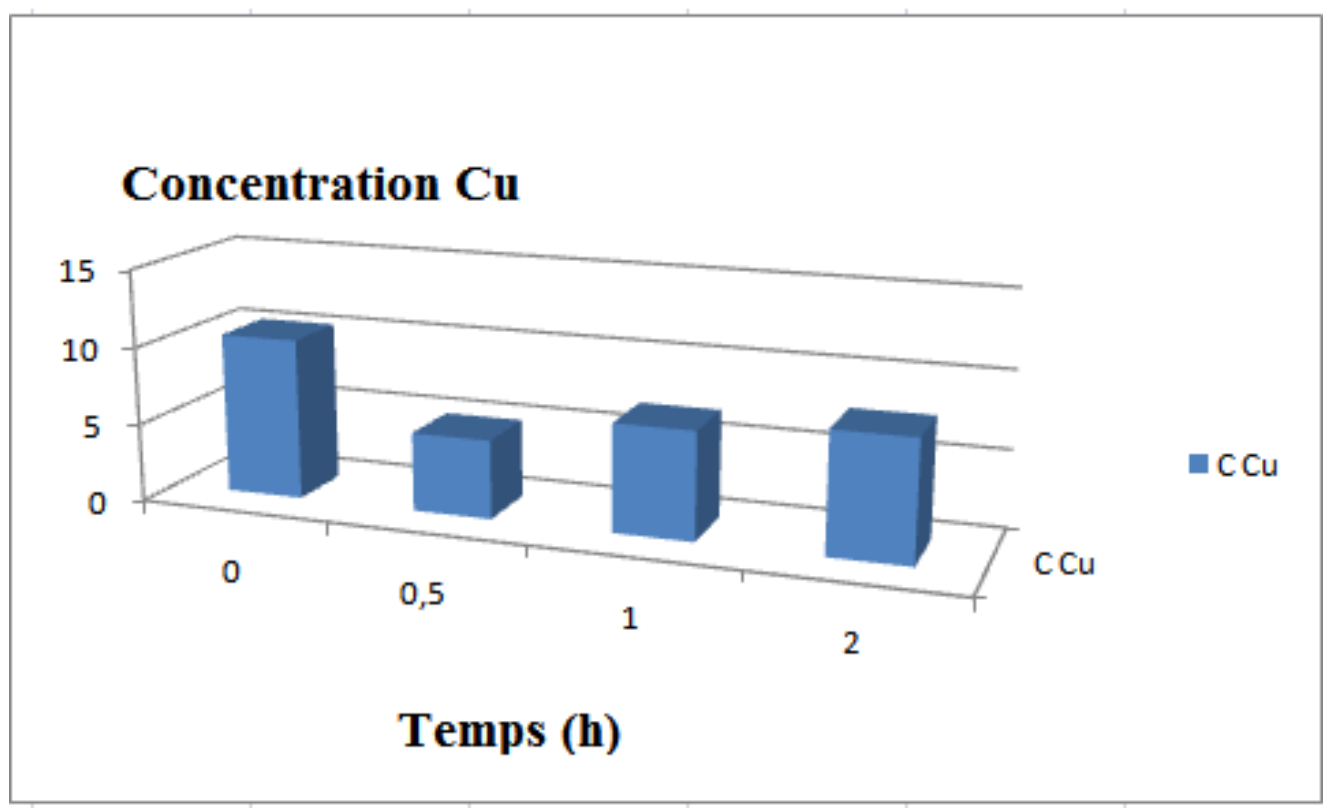

Figure 5: Concentration of copper in the different solutions after treatments by the seeds.

It should be noted that even the color of the solution has decrease proof of the elimination of the copper of the solution.

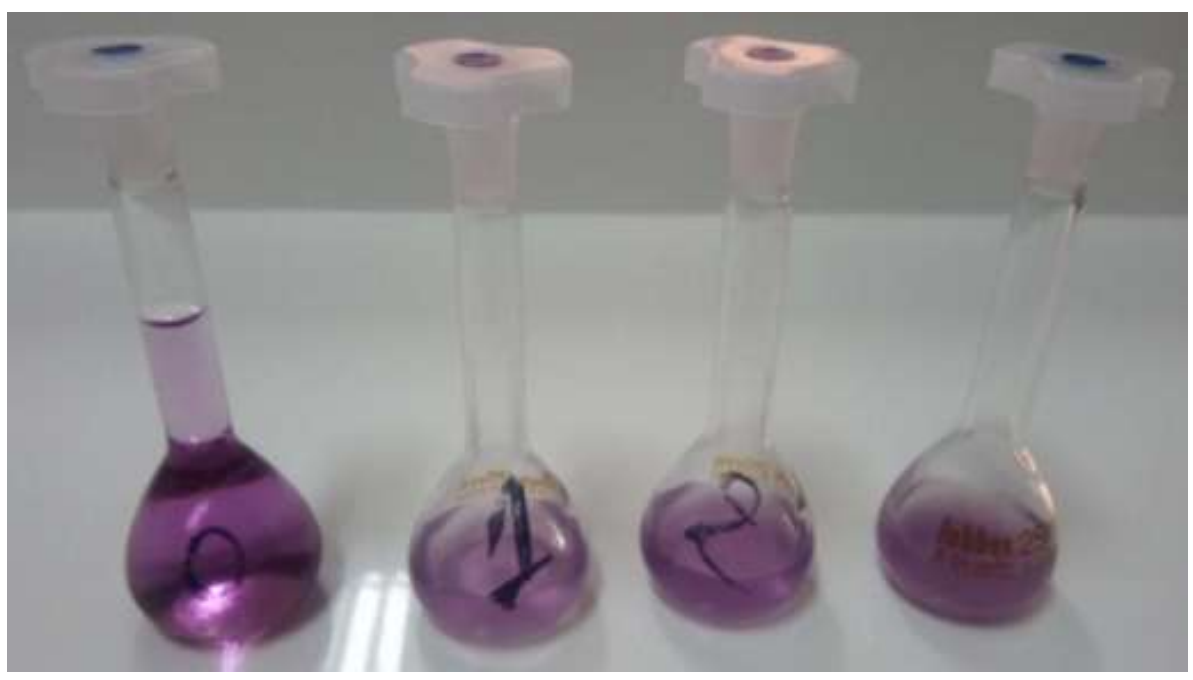

Figure 6: Solutions after treatment and analysis.

The outcomes acquired in this examination were similar with the presentation accomplished in substantial metal evacuation by past laborers, for example, Muyibi et al., utilizing MOS extracts [25]. The MOS ability to expel copper from a water contingent is upon chemical piece of the plant and test state of the procedure. For instance, Subramanium et al. detailed that MO seed cake has had the option to 
evacuate copper $(\mathrm{Cu})$ up to $90 \%$. The grouping of $\mathrm{Cu}$ after the treatment was in the scope of the standard drinking water [26]. For other metal we note crafted by Ravikumar $\mathrm{K}$ at al., that report that the ideal dose of Moringaoleifera watery concentrate with expulsion efficiencies were $95 \%, 93 \%, 76 \%$ and $70 \%$ of copper, lead, cadmium and chromium respectively [27].Different plants can be later joined with different kinds of plants.

The carboxylic acid and hydroxyl groups are introduced in MOS assume a noteworthy job in the evacuation of substantial metal particles. The rate of evacuations of Copper were (95\%) by the MOS from India. Biosorption can be characterized as the capacity of organic materials official with overwhelming metal from wastewater. The dynamic specialists in this plant are glucosinolates and phenolics, which are the practical gatherings that are fit for securing metals. Biosoption action could be clarified by the charge-fix system because of low subatomic weight and high charge density [28, 29].

\section{Conclusion}

In this investigation, the MOSs from Mali was a proficient regular adsorbent material of copper from watery arrangements. The MOS ability to evacuate copper relies upon numerous rules as; plant assortment and states of examinations. Up to now, various advancements have been created for the evacuation of $\mathrm{Cu}$ (II) from wastewater. Nevertheless, the use of these techniques has been obstructed by some natural restrictions, including high capital and upkeep cost, costly gear, high affectability to operational conditions, critical vitality utilization, or inadequate metal expulsion.

The biosorbent (seeds of Moringa with $\mathrm{Cu}^{2+)}$ was treated with $100 \mathrm{ml}, 0.1 \mathrm{M} \mathrm{HNO}_{3}$ in first with consistent blending for 2 hours to expel metals from the biosorbent and increment its surface zone. The arrangement is filtred and the biosorbent was separated with $200 \mathrm{~mL}$ ethanol to expel inorganic and natural issue from the sorbent surface. This was done for 2 hours 30 minutes. The adsorbent $\mathrm{pH}$ was changed in accordance with 7 utilizing $0.1 \mathrm{M} \mathrm{NaOH}$, washed with refined water, stove dried for around 60 minutes, kept in a hermetically sealed plastic holder and put in a fridge at $4^{\circ} \mathrm{C}$ to another utilization.

Along these lines, the advancement and improvement of seeds of Moringa as a characteristic adsorbent offers numerous particular focal points to numerous nations of the creating scene. It could be seen as manageable, fitting, successful, and strong water treatment.

Our examination is going on the investigation of expulsion parameters, for example, contact time, $\mathrm{pH}$, temperature, molecule size, sorbent portion, and starting metal fixation. In the future, the combination of sustainable biomedical techniques with cyber-physical systems using wireless sensor and actuators networks and Nano-robots will make possible to perform localized mitigation and treatment of pollutants to lessen the massive work of water treatment plants $[30$, $31]$.

\section{Acknowledgments}

We are thankful to Pr.Morad Naoum: Director of Maghnia Center University, for the excellent working conditions and facilities.We are additionally thankful to Fatoumata Samake for giving the seeds of Moringa Oleifera bring back from Mali. 


\section{Conflict of interest statement}

We assure you that we have no relation with any financial organization concerning the subject discussed and the material chosen

\section{Authors' biography}

Dr. Assia Keniche, was born in Tlemcen (Algeria). Graduated in chemistry at university of Tlemcen, Algeria. $\mathrm{PhD}$ of Bioorganic and therapeutic at university of Tlemcen (Algeria). Now teaching and researching on Medicinal Chemistry. Work on natural derived-products, synthesis, purification and analysis of new compounds that might used as drugs, new material and in phytoepuration.

Dr. Leshaf Anissa, was born in Tlemcen(Algeria). Graduated in chemistry at university of Tlemcen, Algeria. Doctor of catalysis and green chemistry at university of Tlemcen (Algeria). Now teaching and researching on Adsorption of Acidol Red 2BE-NW Dye from Aqueous Solutions on Carboxymethyl Cellulose/Organo-Bentonite Composite: Characterization, Kinetic and Thermodynamic Studies. Influence of heat treatment of iron oxide on its effectiveness as anticorrosion pigment in epoxy based coatings.

Dr.AsmaKhelassi, was born in Tlemcen (Algeria). Graduated in chemistry at university of Tlemcen, Algeria. Doctor of thermodynamic at university of Tlemcen (Algeria). Now teaching and researching on study experimental and modeling of equilibrium of liquid vapor of binary system containing ionic liquids.

\section{References}

[1] Abreu L.M., Hora H. R. M. , Rangel J. J. A., Erthal Jr M. , Razmjooy N., Estrela V. V., Edoh T., Oliveira G. G., Iano Y.; A Multi-Criteria Modelling For Ranking Co2 Emitting G20 Countries From The Kaya And Their Impacts On Elderly Health. BTSym 2019 Proceedings.ISSN 2447-8326.V.1, 2020, Springer Nature.

[2] Oliveira G. G., Iano Y., Estrela V. V., Monteiro A. C. B., Franca R. P., Pajuelo D.; Sustainability Techniques in Civil Construction. BTSym 2019 Proceedings.ISSN 24478326.V.1, 2020, Springer Nature.

[3] Thiagarajan Y., Estrela V. V., Edoh T., Oliveira G. G., Monteiro A. C. B., Franca R. P., Iano Y., Razmjooy N., Hora H.R.M.; Digital Garbage Bin Monitoring System (Dgbms): A Smart Garbage Monitoring And Management Cyber-Physical System. BTSym 2019 Proceedings.ISSN 2447-8326.V.1, 2020, Springer Nature.

[4] Alessandra Martins Coelho, Vania Vieira Estrela Joaquim Teixeira de Assis and Gil de Carvalho (March 7th 2012). Methodology for Optimization of Polymer Blends Composition, Principal Component Analysis - Engineering Applications, ParinyaSanguansat, IntechOpen, doi: https://doi.org/10.5772/37504

[5] Environmental Degradation Causes and Remediation Strategies, VOLUME 1, Editor Vinod Kumar, Co-editor(s): Jogendra Singh Pankaj Kumar, 2020, p.257.https://doi.org/10.26832/aesa-2020-edcrs

[6] World Health Organization, (2004).Guidelines for Drinking-water Quality.Vol. 1, Third Edition.World Health Organization: Geneva.

[7] L. S. Silva, G. Moreira, B.A. Curzio, F.V. da Fonseca, Micropollutant Removal from Water by Membrane and Advanced Oxidation Processes-A Review, Journal of Water Resource and Protection.; 9,411-431 (2017). doi:https://doi.org/10.4236/jwarp.2017.95027

[8]Khairia M. Al-Qahtani, Assessment and Treatment some of the Local Seeds then used in Removal of Heavy Metals, Journal of American Science 2015;11(11).

[9] C.N.Sawyer, P. L. McCarty, G. F. Parkin,Chemistry for Environmental Engineering and Science: Fifth Edition. McGraw Hill Companies, Inc., Boston (2003).

[10] J.Walker-Smith, J.Blomfield,Wilson's disease or chronic copper poisoning?, Archives of Disease in Childhood, 1973, 48, 476. https://doi.org/10.1136/adc.48.6.476 PMid:4712779 PMCid:PMC1648447 
[11] Y. J.Li,X. P.Zeng, Y. F.Liu, S. S.Yan, Z. H.Hu, Y. M. Ni, Study on the treatment of copper-electroplating wastewater by chemical trapping and flocculation. Sep. Purif. Technol.; 31, 91-95 (2003).doi: https://doi.org/10.1142/9789812791924_0059

[12] D. Kozodynska, Cu(II), Zn(II), Ni(II), and Cd(II) complexes with HEDP removal from industrial effluents on different ion exchangers. Ind. Eng. Chem. Res.;49, 2388-2400 (2010).doi: https://doi.org/10.1016/j.cherd.2013.01.019

[13] H. Polat, D. Erdogan, Heavy metal removal from waste waters by ion flotation. J. Hazard. Mater.;148, 267-273 (2007). https://doi.org/10.1016/j.jhazmat.2007.02.013 PMid:17374447

[14] A. J.Chaudhary, S. M.Grimes, A combined photolytic-electrolytic system for the simultaneous recovery of copper and degradation of phenol or 4-chlorophenol in mixed solutions.

Chemosphere.;72, 1636-1642

(2008). doi:https://doi.org/10.1016/j.chemosphere.2008.05.048 PMid:18597812

[15] E. Csefalvay, V. Pauer, P. Mizsey, Recovery of copper from process waters by nanofiltration and reverse osmosis. Desalination.; 240, 132-142. https://doi.org/10.1016/j.desal.2007.11.070

[16] Chang, S. H.; Teng, T. T.; Ismail, N. Extraction of $\mathrm{Cu}(\mathrm{II})$ from aqueous solutions by vegetable oil-based organic solvents. J. Hazard. Mater. 2010, 181 , 868-872 (2009).doi:https://doi.org/10.1016/j.jhazmat.2010.05.093 PMid:20638965

[17] M.Helen Kalavathy,Lima Rose Miranda, Moringa oleifera-A solid phase extractant for the removal of copper, nickel and zinc from aqueous solutions, Chemical Engineering Journal Volume 158, Issue 2, 1 April 2010, Pages 188-199

[18] Z.Shirani, C.Santhosh, J.Iqbal, A.Bhatnaga , Waste Moringaoleifera seed pods as green sorbent for efficient removal of toxic aquatic pollutants, Journal of Environmental Management,22795-106 (2018). doi: https://doi.org/10.1016/j.jenvman.2018.08.077 PMid:30172163

[19] Thekkudan, V. N.; Vaidyanathan, V. K.; Ponnusamy, S. K.; Charles, C.; Sundar, S.; Vishnu, D.; Anbalagan, S.; Vaithyanathan, V. K.; Subramanian, S., Review on nanoadsorbents: a solution for heavy metal removal from wastewater. IET nanobiotechnology 2017, 11, (3), 213-224. https://doi.org/10.1049/iet-nbt.2015.0114 PMid:28476976

[20] D. B. Kumssa, E. J. Joy, S.D. Young, D. W. Odee, E. L. Ander, M. R. Broadley, Variation in the mineral element concentration of Moringaoleifera lam. and M. stenopetala (Bak. F.) cuf.: Role in human nutrition. PLoS One.; 12, 175503 (2017).doi: https://doi.org/10.1371/journal.pone.0175503 PMid:28388674 PMCid:PMC5384779

[21] B. A. Nordmark, T. M. Bechtel, J. K. Riley, D. Velegol, S. B. Velegol, T.M. Przybycien, R. D. Tilton, Moringaoleifera Seed Protein Adsorption to Silica: Effects of Water Hardness, Fractionation, and Fatty Acid Extraction, Langmuir.; 34, 4852-4860 (2018).doi: https://doi.org/10.1021/acs.langmuir.8b00191 PMid:29566490

[22] K. Shebek, A. B. Schantz, I. Sines, K. Lauser, S. Velegol, M. Kumar, The flocculating cationic polypetide from moringaoleifera seeds damages bacterial cell membranes by causing membrane fusion.Langmuir.; 31, $4496 \quad-4502 \quad$ (2015).doi: https://doi.org/10.1021/acs.langmuir.5b00015 PMid:25845029

[23] T.C.Shan, M.AlMatar, E.A. Makky, E.N. Ali, The use of Moringaoleifera seed as a natural coagulant for wastewater treatment and heavy metals removalAppl Water Sci.;7, 1369-1376 (2017). doi: https://doi.org/10.1007/s13201-016-0499-8

[24] S.A. Muyibi, M. M. J. M. Noor, T. K. Leong, L.H. Loon, Effects of oil extraction from Moringaoleifera seed on Coagulation of Turbid water. International Journal of Environmental Studies.; 59, 243-254 (2002).doi: https://doi.org/10.1080/00207230210924 [25] S.A. Muyibi, E.S.M. Ameen, M.M.J.M. Noor, F.R. Ahmadum, Bench Scale Studies for Pre-treatment of Sanitary Landfill Leachate with Moringaoleifera seed Extract. International $\begin{array}{lllll}\text { Journal of } & \text { Environmental } & \text { Studies.;59, 2002).doi: }\end{array}$ https://doi.org/10.1080/00207230212731

[26] S.Subramanium, N.Vikashni, M. Matakite,Moringaoleifera and other local seeds in water purification in developing countries.,Res J Chem Environ.; 15, 135-138 (2011).

[27].Ravikumar K., Prof.Sheeja A.K., Heavy Metal Removal from Water using Moringaoleifera Seed Coagulant and Double Filtration, International Journal of Scientific \& Engineering Research, 2013, 4, 2229-5518.

[28] K.Jiraungkoorskul, W.Jiraungkoorskul,Moringaoleifera: A new challenge reducing heavy metal toxicity: A review Indian J. Agric. Res.;50, 199-205 (2016). https://doi.org/10.18805/ijare.v0iOF.9361 
Medical Technologies Journal, Volume: 4, Issue: 1, January-March 2020, Pages: 504-515.

Doi :https://doi.org/10.26415/2572-004X-vol4iss1p504-515

[29] C.Mudenur, L.G.Sorokhaibam, V.Bhandari, S.Raja, V.V. Ranade, Green approach to Dye Wastewater Treatment using Biocoagulants, ACS Sustainable Chem. Eng.;4, 24952507 (2016). doi: https://doi.org/10.1021/acssuschemeng.5b01553

[30] Estrela, V. V., A. C. B. Monteiro, R. P. França, Y. Iano, A. KHELASSI, and N. Razmjooy. "Health 4.0: Applications, Management, Technologies and Review". Medical Technologies Journal, Vol. 2, no. 4, Jan. 2019, pp. 262-76, doi: https://doi.org/10.26415/2572-004X-vol2iss4p262-276

[31] Estrela, V.V.; Saotome, O.; Loschi, H.J.; Hemanth, J.; Farfan, W.S.; Aroma, J.; Saravanan, C.; Grata, E.G.H. Emergency Response Cyber-Physical Framework for Landslide Avoidance with Sustainable Electronics. Technologies, 2018, 6, 42. doi: https://doi.org/10.26415/2572-004X-vol2iss4p262-276 